\title{
The Lack of Legal Aid Accessed by The Poor Society in West Kalimantan Province
}

\author{
Rini Setiawati ${ }^{1}$, Sri Ayu Septinawati ${ }^{2}$, Charlyna S. Purba ${ }^{3}$ \\ \{rini090366@gmail.com ${ }^{1}, \underline{\text { septin2006@yahoo.co.id }}{ }^{2}$, charlyna.purba@ gmail.com ${ }^{3}$ \}
}

Faculty of Law Universitas Panca Bhakti Pontianak, Indonesia ${ }^{1,2,3}$

\begin{abstract}
Providing legal aid to the poor in West Kalimantan was one of the state's role manifestations in providing legal protection as ruled by 16th Indonesian Law of 2011 on Legal Aid. In fact, the authors found that most of the poor society in West Kalimantan faced the difficulty to access the legal aid. It was caused by the lack of verified legal aid providers in West Kalimantan. The aim of the study was finding the solution to maximize the legal aid providers within giving the legal aid to the poor society. Through unstructured legal method, the study found that there was a legal vacuum of the unruled mechanism which institutions that provide verification of legal aid institutions established by the Local Government. The implication of the study gave a recommendation in the form of legislation revision that legal aid regulations need further arrangements in the 16th Indonesian Law of 2011 on Legal Aid.
\end{abstract}

Keywords: Legal Aid, Poor Society, Access.

\section{Introduction}

Article 27 paragraph (1) The 1945 Constitution of the Republic of Indonesia (SekretariatNegara-RI, 2002) mentioned that all citizens shall be equal before the law and the government and shall be required to respect the law and the government, with no exceptions. Equality before the law can be realized and enjoyed by the community if there was an equal opportunity to get justice (Gerstenberg, 2012). Equality before the law might be accompanied by various facilities for the public to obtain justice too including legal aid right fulfillment (Sir \& Brooke, 2017).

There were many poor society which is entangled in legal cases and could not able to afford legal counsel services in accompanying his case became one of the establishment reasons in the form of legal aid regulation. Legal aid was a legal service provided by legal aid providers, free of charge to legal aid recipient. Legal aid recipient was a poor person or group. While, legal aid provider was a legal aid agency or civic organization that provide legal aid services based on The 16th Indonesian Law of 2011 on Legal Aid (The Republic of Indonesia, 2011).

Legal aid provider role in providing legal assistance in the proceedings for the poor is very important (Iwan Wahyu Pujiarto, Syafrudin Kalo, Eka Putra, 2015). The reason was very sure because the poor society which entangled in legal cases had not understood their rights as defendants, it made them were treated unfairly or impaired their right. Meanwhile, firmly in The 1945 Constitution of the Republic of Indonesia stated that every citizen had the same right before the law and was entitled to be treated fairly (Sekretariat-Negara-RI, 2002). 
Legal aid providers was brought by central government's policy in fact was a clearly appropriate but also crippled. Is was caused by the current problems especially for the rural poor, including West Kalimantan Province in gaining access to justice (Cassese, 2016) through obtain mentoring from legal aid providers. Any legal aid agency must be verified and accredited to be able to provide legal assistance and access the budget were mentioned in The 16th Indonesian Law of 2011 on Legal Aid. These were the problems and would be answered in this issue.

\section{Literature Review}

The realization of the state of Indonesia as a constitutional state, everybody constitutional right is guaranteed to gain recognition, guarantee (Bies, 1993), protection, legal certainty and equal treatment before the law as a means of human rights protection (Zick, n.d.).

Article 27 paragraph (1) The 1945 Constitution of the Republic of Indonesia (SekretariatNegara-RI, 2002) sounds -All citizens shall be equal before the law and the government and shall be required to respect the law and the government, with no exceptions $\|$. Then, Article 28 D paragraph (1) The 1945 Constitution of the Republic of Indonesia (Sekretariat-Negara-RI, 2002) stated that -Every person shall have the rights to recognition, guarantees, protection and certainty before a just law, and of equal before the lawl. Next, Article 28I paragraph (1) The 1945 Constitution of the Republic of Indonesia (Sekretariat-Negara-RI, 2002) mentions - The rights to life, freedom from torture, freedom of thought and conscience, freedom of religion, freedom from enslavement, recognition as a person before the law, and the right to not to be tried under a law with retrospective effect are all human rights that cannot be limited under any circumtances\|. The last but not at least, Article 34 paragraph (1) The 1945 Constitution of the Republic of Indonesia (Sekretariat-Negara-RI, 2002) mentioned that - Impoverished persons and abondoned children shall be taken care of by the Statell.

Besides that, the state is responsible for poor society legal assistance provision as a manifestation of access to justice oriented to social change realization (Bernts \& Faculty, 1992). Article 1 paragraph 1 of The 16th Indonesian Law of 2011 on Legal Aid (The Republic of Indonesia, 2011) finds the meaning of legal aid is a legal service provided by legal aid providers, which free of charge for legal aid recipients. Legal aid recipient is a poor person or group, whereas legal aid providers is a legal aid organization or civic organization providing legal aid services under The 16th Indonesian Law of 2011 on Legal Aid.

Based on these provisions, then the state recognizes poor society economic rights, social rights, cultural rights, civil rights and political rights. On the basis of these considerations, the poor society have the right to be accompanied in the lawsuit that is being experienced and to be defended by both litigation and non litigation lawyers. Litigation is the process of handling legal cases conducted through the court to solve them. While, non litigation is the process of handling lawsuits conducted outside the court to solve them.

Legal assistance provided to legal aid recipients includes exercising power, accompanying, representing, defending and/or carrying out other legal actions for the legal benefit of the legal aid recipients.

The next provisions in this Indonesian Law, Article 8 mention that the implementation of legal assistance is carried out by qualified legal aid providers, including: 1) incorporated; 2) accredited under this The 16th Indonesian Law of 2011 on Legal Aid; 3) have a permanent office or secretariat; 4) has a board; 5) has a legal aid program. Accreditation shall be obtained 
based on the results of the assessment conducted by the Minister to fulfill the feasibility of providing legal aid by forming a committee consisting of ministries conducting legal affairs in the field of law and human rights; academics; public figure; and institutions or organizations providing legal aid services.

\section{Research Method}

The type of the research is qualitative research method, especially dogmatic legal research. Phase of research is exploratory research through unstructured method and then hypothesis building. Data were collected by library reseach. The purpose of the study is to explore how the lack of legal accessed by the poor society in West Kalimantan Province could be happen. The scope of the research is Indonesia Law related to legal aid.

\section{Result And Discussion}

\subsection{The Difficulty to be Verified Legal Aid Provider}

The difficulty of becoming a verifiable legal aid agency is one of the reasons for the difficulty of the poor accessing legal aid. The provision of Article 6 The 16th Indonesian Law of 2011 on Legal Aid mention as follows (The Republic of Indonesia, 2011):

(1) Bantuan hukum diselenggarakan untuk membantu penyelesaian permasalahan hukum yang dihadapi Penerima Bantuan Hukum.

(2) Pemberian Bantuan Hukum kepada Penerima Bantuan Hukum diselenggarakan oleh Menteri dan dilaksanakan oleh Pemberi Bantuan Hukum berdasarkan Undang-Undang ini.

(3) Menteri sebagaimana dimaksud pada ayat (2) bertugas:

a. menyusun dan menetapkan kebijakan penyelenggaraan Bantuan Hukum;

b. menyusun dan menetapkan Standar Bantuan Hukum berdasarkan asas-asas pemberian Bantuan Hukum;

c. menyusun rencana anggaran Bantuan Hukum;

d. mengelola anggaran Bantuan Hukum secara efektif, efisien, transparan, dan akuntabel; dan

e. menyusun dan menyampaikan laporan penyelenggaraan Bantuan Hukum kepada Dewan Perwakilan Rakyat pada setiap akhir tahun anggaran.

The provision mentioned above states that the actual implementation of the Legal Aid is organized by the Minister and implemented by the legal aid providers. Tugas menteri dalam hal penyelenggaraan bantuan hukum ini, diantaranya:

1. compile and set policy,

2. compile and set standards,

3. preparing budget,

4. manage budgets, and

5. prepare and submit reports to the House of Representatives at the end of each fiscal year.

Means, the legal aid providers are very much tied to the Minister. The position of legal aid providers is limited to organizers in terms of policies, standards, and budgets. Other than 
that, The 16th Indonesian Law of 2011 on Legal Aid has determined that those who can provide legal assistance are verified and accredited legal aid providers.

This is stated in Article 7 Un The 16th Indonesian Law of 2011 on Legal Aid contains (The Republic of Indonesia, 2011):

(1) Untuk melaksanakan tugas sebagaimana dimaksud dalam Pasal 6 ayat (3), Menteri berwenang:

a. mengawasi dan memastikan penyelenggaraan Bantuan Hukum dan pemberian Bantuan Hukum dijalankan sesuai asas dan tujuan yang ditetapkan dalam UndangUndang ini: dan

b. melakukan verifikasi dan akreditasi terhadap lembaga bantuan hukum atau organisasi kemasyarakatan untuk memenuhi kelayakan sebagai Pemberi Bantuan Hukum berdasarkan Undang-Undang ini.

(2) Untuk melakukan verifikasi dan akreditasi sebagaimana dimaksud pada ayat (10 huruf b, Menteri membentuk panitia yang unsurnya terdiri atas:

a. kementerian yang menyelenggarakan urusan pemerintahan di bidang hukum dan hak asasi manusia;

b. akademisi;

c. tokoh masyarakat; dan

d. lembaga atau organisasi yang memberi layanan Bantuan Hukum.

(3) Verifikasi dan akreditasi sebagaimana dimaksud pada ayat (1) huruf b dilakukan setiap 3 (tiga) tahun.

(4) Ketentuan lebih lanjut mengenai tata cara verifikasi dan akreditasi sebagaimana dimaksud pada ayat (1) huruf b diatur dengan Peraturan Menteri.

Because the Minister also oversees and ensures the provision of legal aid and provision of legal assistance is carried out in accordance with the established principles and objectives, attached the task of verification and accreditation of legal aid organizations or community organizations to meet the feasibility of providing legal aid.

This verification and accreditation process is conducted once in 3 (three) years by the minister by forming a committee consisting of ministries conducting government affairs in the field of law and human rights, academia, community leaders and institutions or organizations providing legal aid services.

The 16th Indonesian Law of 2011 on Legal Aid does not set out in detail the provisions on the procedures for verification and accreditation. However, it is further stipulated in ministerial regulations, that is The 3rd of Regulation of the Minister of Law and Human Rights of 2013 on Procedures for Verification and Accreditation of Legal Aid Institutions or Societal Organizations. Stages (Hukum, Hak, Manusia, \& Indonesia, 2013) in performing verification and accreditation is done in the following manner:

1. announcement

2. application

3. administrative checks

4. factual checking

5. the classification of legal aid providers

6. the establishment of legal aid providers 
The complexity of the verification and accreditation process has become one of the pros and cons among the legal aid providers. On the one hand the objective is for the provision of legal aid in accordance with the principle of justice (Moore, 2002), equality in law, openness, efficiency, effectiveness, and accountability. However, on the other hand it is against the goal to be achieved.

How come, the difficulty of becoming an accredited legal aid provider becomes a new problem and an obstacle to ensuring and fulfilling the right for legal aid recipients to gain access to justice (Moore, 2002), realizing the constitutional rights of all citizens (Resnik, 2013) in accordance with the principle of equality of positions within the law, to ensure the certainty of the provision of legal aid equally throughout the territory of the Republic of Indonesia, and to realize an effective, efficient and accountable judiciary.

\subsection{The Lack of Verified Legal Aid Providers in West Kalimantan Province}

West Kalimantan Province is the fourth largest province in Indonesia, with the surrounding area $146.807 \mathrm{~km}^{2}$ or 7,53 percent of Indonesia or 1,13 times of Java island. Based on West Kalimantan Provincial Government official website it is known that there is 14 (fourteen) districts/cities, including Pontianak City, Singkawang City, Mempawah Regency, Sambas Regency, Bengkayang Regency, Landak Regency, Sanggau Regency, Sintang Regency, Kapuas Hulu Regency, Ketapang Regency, Sekadau Regency, Melawi Regency, Kubu Raya Regency, and Kayong Utara Regency.

The extend and the number of regions in West Kalimantan Province is unbalanced with a verified and accredited legal aid agency. From the fourteen regencies/cities there are only 3 (three) regencies/cities whose have the verified and accredited legal aid providers currently.

On January 7 of 2016, come through the Minister of Justice and Human Rights of the Republic of Indonesia Decision of 2016 Number M.HH-01.HN.03.03 on Institutions/Legal Aid Organizations Passed Verification of Accreditation as Legal Aid for the Period of 2016 to 2018 stipulates that the institutions mentioned in the annex may provide legal assistance and access the legal aid budget in accordance with applicable laws and regulations. The decision stipulates that there are a number of 405 (four hundreds and five) verified legal aid institutions spread throughout the provinces region in Indonesia, 6 (six) legal aid institutions of them are in West Kalimantan Province.

Legal aid institutions in West Kalimantan Province can be shown as the following table:

Table 1. Legal Aid Institutions in West Kalimantan Province

\begin{tabular}{|c|l|c|}
\hline No. & \multicolumn{1}{|c|}{ Insitution } & Region \\
\hline 1 & $\begin{array}{l}\text { Biro Konsultasi dan Bantuan Hukum Fakultas Huk } \\
\text { Universitas Tanjungpura }\end{array}$ & Pontianak City \\
\hline 2 & Posbakumadin Pengadilan Negeri Pontianak & Ketapang Regency \\
\hline 3 & Gerakan Masyarakat (Gema) Bersatu Ketapang & Pontianak City \\
\hline 4 & $\begin{array}{l}\text { Lembaga Kajian dan Konsultasi Bantuan Hukum } \\
\text { Fakultas Hukum Universitas Panca Bhakti }\end{array}$ & Singkawang City \\
\hline 5 & $\begin{array}{l}\text { Lembaga Konsultasi dan Bantuan Hukum } \\
\text { Perempuan dan Keluarga (LKBH PEKA) }\end{array}$ & Mempawah Regency \\
\hline 6 & Galaherang & Remang \\
\hline
\end{tabular}

Source: West Kalimantan Regional Office of The Ministry of Justice and Human Rights

Based on the table above show the lack of verified legal aid institutions. It creates the difficulty of reaching the whole community in West Kalimantan Province. Of course when 
compared with the the extend and the number of regions in West Kalimantan Province making effective legal aid to the poor society is something mission impossible to do.

\subsection{The Lack of Regions in West Kalimantan Province in Having Local Law on Legal Aid}

The government administration system in Indonesia divides between central and local government. Local government (Carr, 2006) is a part that can not be separated from the state implementation. The success of local government will affect the state governance implementation successful as a central government. The local governance principle (The Republic of Indonesia, 2014) based on legal certainty principle, orderly state organizers principle, public interest principle, openness principle, proportionality principle, professionalism principle, accountability principle, efficiency principle, effectiveness principle and fairness principle (Bernts \& Faculty, 1992).

Principles of governance are implemented in the form of policies in the form of local regulations that can be established by the region to provide legal certainty to the implementation. A legislation may be established under the direct conditions governing it. Local Law establishment about legal aid is a direct command of the higher legislation, it is Article 19 The 16th Indonesian Law of 2011 on Legal Aid admits that (The Republic of Indonesia, 2011):

(1) Daerah dapat mengalokasikan anggaran penyelenggaraan Bantuan Hukum dalam Anggaran Pendapatan dan Belanja Daerah.

(2) Ketentuan lebih lanjut mengenai penyelenggaraan Bantuan Hukum sebagaimana dimaksud pada ayat (1) diatur dengan Peraturan Daerah.

In West Kalimantan Province which devided into 14 regions of regencies/cities, there are only 2 (two) of them whose have legal aid in their local laws. diantaranya yang memiliki peraturan daerah tentang Bantuan hukum as shown in the following table:

Table 2. Check List Regions in West Kalimantan Province with their Local Law on Legal Aid

\begin{tabular}{|c|c|c|c|c|}
\hline \multirow[t]{2}{*}{ No. } & \multirow[t]{2}{*}{ Regency/City } & \multicolumn{2}{|c|}{ Local Law } & \multirow[t]{2}{*}{ Description } \\
\hline & & Yes & No & \\
\hline 1 & Sambas Regency & $\sqrt{ }$ & & $\begin{array}{l}\text { The 11th Sambas Regency Local Law of } \\
2015 \text { on Legal Aid Enforcement }\end{array}$ \\
\hline 2 & Mempawah Regency & & $\sqrt{ }$ & - \\
\hline 3 & Sanggau Regency & & $\sqrt{ }$ & In making process \\
\hline 4 & Ketapang Regency & & $\sqrt{ }$ & - \\
\hline 5 & Sintang Regency & & $\sqrt{ }$ & - \\
\hline 6 & Kapuas Hulu Regency & & $\sqrt{ }$ & - \\
\hline 7 & Bengkayang Regency & & $\sqrt{ }$ & - \\
\hline 8 & Landak Regency & & $\sqrt{ }$ & - \\
\hline 9 & Sekadau Regency & & $\sqrt{ }$ & - \\
\hline 10 & Melawi Regency & & $\sqrt{ }$ & - \\
\hline 11 & Kayong Utara Regency & $\sqrt{ }$ & & $\begin{array}{l}\text { The 5th Kayong Utara Regency Local } \\
\text { Law of } 2015 \text { on Legal Aid to the Poor }\end{array}$ \\
\hline
\end{tabular}




\begin{tabular}{|r|l|r|r|r|}
\hline 12 & Kubu Raya Regency & & $\sqrt{ }$ & - \\
\hline 13 & Pontianak City & & $\sqrt{ }$ & - \\
\hline 14 & Singkawang City & & $\sqrt{ }$ & - \\
\hline
\end{tabular}

The table above shows that there are only Sambas Regency (Negara, 2015) and Kayong Utara Regency (Kayong Utara Regent, 2015) who already have local law on legal aid. While, other areas do not have local law on legal aid until the time of this writing. Information obtained by author from West Kalimantan Ministry of Law and Human Rights Regional Office stated that now a days Sanggau Regency Local Government is currently drafting a Local Law on Legal Aid.

Meanwhile, if we return to pay attention to legal aid agencies are verified and accredited based Minister of Justice and Human Rights of the Republic of Indonesia Decision of 2016 Number M.HH-01.HN.03.03 on Institutions/Legal Aid Organizations Passed Verification of Accreditation as Legal Aid for the Period of 2016 to 2018, then there will be no verified and accredited legal aid agencies in the regions of Kayong Utara Regency and Sambas Regency.

Although Kayong Utara Regency and Sambas Regency have had local law on legal aid, in fact precisely in that area there has not been any verified and accredited legal aid institutions. A verified and accredited legal aid institution is located in Pontianak City, Ketapang Regency, Singkawang City and Mempawah Regency which has no local legislation on legal aid.

\subsection{The Urgency of Giving the Authority for Local Government to do a Verification and Acreditation againts Legal Aid Institution}

The lack of legal aid implementation in West Kalimantan Province influenced by several things as described above, such as the number of verified and accredited legal aid providers the number is still very minimal, areas that have local legislation on legal aid are still minimal, and the extend of West Kalimantan Province so it has not been able to reach out to people in areas that need legal aid. This problem is certainly very detrimental to the poor in West Kalimantan Province who needs legal aid. Absolutely, this is not in accordance with the role and purpose of the state in order to realize the welfare of society, including the poor society in West Kalimantan Province which requires legal assistance. Effectiveness problems in providing legal aid to poor society in West Kalimantan Province can be solved with a solution, namely authority granting to the Local Government to conduct the legal aid providers verification and accreditation.

The granting of this authority may be carried out as an extension of the interpretation of further regulatory provisions relating to the arrangement of the provision of legal aid which can be regulated by local law as mentioned in Article 19 The 16th Indonesian Law of 2011 on Legal Aid. Authority granting the local government to verify and accreditation of legal aid will greatly support the purpose of providing legal assistance, in particular ensuring equitable legal aid implementation throughout the unitary state of the Indonesian republic.

This is because of legal aid providers accreditation procedures will be adjusted to the conditions and potential of each region without reducing the quality and benefits obtained by the poor to access justice (Dowd, 1987) through legal aid providing. So, based on local government principle as regulated by The 23th of Indonesian Law of 2014 on Local Government, namely as widely as autonomy principle and co-administration task (The Republic of Indonesia, 2014). Autonomy principle (Pratchett, 2004) is the basic local government principle based on local autonomy. Local autonomy (Clark, 1984) is the rights, authority, and authonom region obligation to regulate and manage their own governmental 
affairs and interests of the local community in the system of Unitary State of the Republic of Indonesia.

No further explanation is found in The 16th Indonesian Law of 2011 on Legal Aid about the local law on legal aid provision. Means, it is become an opportunity and the possibility for local government to do a verification and acreditation for the legal aid institution in the regions.

In addition, the sollution will greatly assist central government, including time effectiveness aspect, institution aspect and budget aspect. The implementation of legal aid provider verifivation and acreditation by local government will reduce the amount of time of legal aid institutions and ministry to prepare and do the verification and acreditation. Then, it will minimize the financing that shoul be required by the legal aid institutions and ministry in order to effort the verification and acreditation if it can be done in the region and not must be in the central which far enough from the regions spead throughout in the Unitary State of the Republic of Indonesia.

\section{Conclusion}

Complicated problems faced by the poor society, including the poor society in West Kalimantan Province to gain access to justice through legal aid is influenced by a number of things, such as the lack of verified and accredited legal aid institutions and have not spread in all regencies/cites in West Kalimantan Province, the lack of regions with local law on legal aid (Sambas Regency and Kayong Utara Regency).

There are only 6 (six) verified and accredited legal aid institutions makes them unable to reach all the poor society in West Kalimantan Province. Maximizing solution for the legal aid provision can be done by authority granting to local government to do a verification and accreditation for the legal aid institutions. This power granting may be incorporated as an integral part of the local law in legal aid. So, all the regions in West Kalimantan Province have to set their own local laws on legal aid.

\section{References}

[1]. Bernts, T., \& Faculty, S. (1992). Citizenship And Social Justice, 5(2), 195-196.

[2]. Bies, R. J. (1993). Organizational Justice Research In The 1990s : Moving In New Directions, 6(L), $1-2$.

[3]. Carr, J. B. (2006). Local Government Autonomy And State Reliance On Special District Governments: A Reassessment. Political Research Quarterly, 59(3), 481-492. Https://Doi.Org/10.1177/106591290605900315

[4]. Cassese, S. (2016). In Praise Of Mauro Cappelletti, 14(2), 443-448. Https://Doi.Org/10.1093/Icon/Mow029

[5]. Clark, G. L. (1984). A Theory Of Local Autonomy. Annals Of The Association Of American Geographers, 74(2), 195-208. Https://Doi.Org/10.1111/J.1467-8306.1984.Tb01448.X

[6]. Dowd, J. J. (1987). Justice In Old Age : An Analysis Of Corporatist Social Theory, 1(4), 477-478.

[7]. Gerstenberg, O. (2012). Negative/Positive Constitutionalism,_Fair Balance, 'And The Problem Of Justiciability, 10(4), 904-925. Https://Doi.Org/10.1093/Icon/Mor085

[8]. Hukum, M., Hak, D. A. N., Manusia, A., \& Indonesia, R. The 3rd Ministry Regulation Of Law And Human Rights Of 2013 On Procedures For Legal Aid Verification And Acreditation Or Community Organizations (2013). 
[9]. Iwan Wahyu Pujiarto, Syafrudin Kalo, Eka Putra, E. I. (2015). Pelaksanaan Pemberi Bantuan Hukum Dikaitkan Dengan Undang-Undang Nomor 16 Tahun 2011 Tentang Bantuan Hukum, 8(3), $318-341$.

[10].Kayong Utara Regent, K. B. P. The 5th Kayong Utara District Local Law Of 2015 On Legal Aid For Poor Society (2015).

[11].Moore, D. (2002). The Sense Of Justice - Introduction, 14(3), 233-234.

[12].Negara, T. L. The 11th Sambas Regency Local Law Of 2015 On Legal Aid, $3 \S$ (2015). Pratchett, L. (2004). Local Autonomy, Local Democracy And The _New Localism‘. Political

[13].Studies. Https://Doi.Org/10.1111/J.1467-9248.2004.00484.X

[14].Resnik, J. (2013). Globalization(S), Privatization(S), Constitutionalization, And Statization: Icons And Experiences Of Sovereignty In The 21st Century, 11(1), 162- 199. Https://Doi.Org/10.1093/Icon/Mos051

[15].Sekretariat-Negara-RI. The 1945 Constitution Of The Republic Of Indonesia, $1 \S$ (2002). Https://Doi.Org/10.1017/CBO9781107415324.004

[16].Sir, B., \& Brooke, H. (2017). The History Of Legal Aid 1945 - 2010, (September).

[17].The Republic Of Indonesia. 16th Indonesian Law Of 2011 On Legal Aid (2011).

[18]. The Republic Of Indonesia. The 23rd Indonesian Law Of 2014 On Local Government (2014).

[19].Zick, T. (N.D.). Rights Dynamism, 791-860. 